\title{
EXPERIMENTAL INVESTIGATION ON FLEXURAL BEHAVIOUR OF HIGH PERFORMANCE CONCRETE USING GLASS FIBRES
}

\author{
Kannan S.U. ${ }^{1}$ Selvamony. C. ${ }^{2}$, Ravikumar M.S. ${ }^{3}$, Basil Gnanappa S. ${ }^{4}$ \\ ${ }^{1,2,3}$ Research Scholar, Sathyabama University, Chennai, India \\ ${ }^{4}$ Moderator Gnanadhason Polytechnic, Nagercoil ,India
}

\section{Abstract}

The experimental work reported in this paper was carried out to study the feasibility of using Glass fibres in concrete as fibre reinforcement. This composite material, which possesses unique qualities of strength, can partly replace the conventional reinforced cement concrete, which is popular and widely used in building construction or in the application. It was originally developed for insulating electrical wiring and later found to have excellent fibre forming capabilities, and is now used almost exclusively as the reinforcing phase in the material commonly known as fiberglass. This paper presents the results and conclusion of an experimental investigation on the strength properties of concrete using glass fibre. Concrete specimens were cast with and without fibres and tested under compression, split tension and flexure as per relevant Indian standard specifications. $M_{30}$ grade of concrete was designed using IS method of mix design. A total of 50 cubes for compressive strength, 50 cylinders for split tensile strength and 50 beams for flexural strength were cast and tested. Fibre contents used in this experimental work were $0 \%, 1 \%, 2 \%, 3 \%, 4 \%, 5 \%$ \& $6 \%$ by weight of aggregate. Water cement ratio adopted has 0.42 . The glass fibres used in this work has an aspect ratio taken in the range of $50-70$. Workability of the concrete was checked with slump cone and consistency by compaction factor test for various percentage fibre additions in the concrete. A tendency towards balling or formation of fibre nodules is a serious problem in FRC and it is avoided in this experimental work by addition of fibre in stages. Tests were conducted at the end of 7 days, 14 days, and 28 days curing. Test results indicate that addition of glass fibres in concrete enhances the strength markedly. It was found that even $1.0 \%$ of fibre content by weight of concrete showed improvement in compressive strength by 7.61 $\%$. Also percentage increase in the strength-to-weight ratio achieved by incorporating glass fibres in concrete is higher than those concrete without glass fibres.

Key words: Fibre reinforced concrete, Composites, Glass Fibres ,flexural strength, compressive strength

\section{INTRODUCTION}

The maintenance, rehabilitation and upgrading of existing structural members are perhaps the most crucial problems in civil engineering today. Reinforced Concrete structures deteriorate for many reasons, such as corrosion of internal reinforcement, chloride attack and freezing and thawing action. Poor initial design and construction faults also render existing $\mathrm{RC}$ structures deficient. The most important reason for strengthening $\mathrm{RC}$ structures, however, is the continuous upgrading of design codes.

Fiber reinforced polymer products have become attractive materials for structural engineers in the concrete construction field, especially for strengthening existing reinforced concrete structural elements. Several FRP systems are now commercially available, incorporating glass, aramid or carbon fibers. FRP products are available in many forms such as fabrics and sheets.
Due to this advantage, the use of FRC has steadily increased in recent days. And its current field of application includes, air port and high way pavements, earth quake-resistant structures, mine and tunnel linings, bridge deck overlays, hydraulic structures, rock-slope stabilization. Extensive research work in FRC has established that addition of various types of fibres such as steel Glass, synthetic, and carbon in plain concrete improves strength, toughness, ductility, post-cracking resistance, etc.

Cement based fibre reinforced concrete increases the tensile strength by delaying the growth of cracks and the toughness is increased by transmitted stress across a cracked section. As a result much longer deformation is possible beyond the peak stress than without fibre reinforcement. FRC is a smart concrete which increases its flexure and tensile strength.

Literature survey indicates that very limited study has been conducted on FRC using glass fibre. Further 
more, with increase in modern trend of lapping of reinforcement bars like couplings in construction work, the quantity of fibres generated from this threading activity will increase in the forth coming years. As a substitute of standard fibres these reinforcement glass fibres can effectively be used for making high-strength low cost FRC. Use of materials has gained significance in the wake of the substantial emphasis on the conversion of agro-industrial $s$ into potential building materials with a " to wealth" or "refuse to resource" approach.

\section{A. Objective of This Study:}

- To study the behaviour of Glass fibre Concrete in compression, tension, flexure.

- To compare the behaviour of Glass fibres with that of plain concrete.

B. Materials:

The Materials Used In This Experiment Investigation Are:

\section{B.1. Cement:}

Ordinary Portland Cement (OPC) 43 grade, Dalmia Super Cement for casting the entire specimen.

\section{B.2. Fine aggregate}

Locally available river sand having following properties was used for casting the entire specimens. Specific gravity: 2.60, Water absorption: 1.0\%, Fineness modulus: 2.92

\section{B.3. Coarse aggregate}

Crushed granite coarse aggregate of maximum size $20 \mathrm{~mm}$ and having following properties was used for casting the entire specimens. Specific gravity: 2.70, Water absorption: $0.5 \%$, Fineness modulus: 7.83

\section{B.4. Water}

Water available in the college campus conforming to the requirements of water for concreting and curing as per BIS $456-2000$ is used for casting and curing the specimens.

\section{B.5. Fibres}

Glass fibres were collected from the construction sites. The aspect ratio is ranging from 50 to 70 . Based on the aspect ratio the glass fibres were segregated and chosen for addition in the concrete. Glass fibres are added to the concrete in varying replacements starting from $0 \%$ to $6 \%$ with an increment of $1 \%$ in total weight of concrete. Glass fibre used in this work is shown below

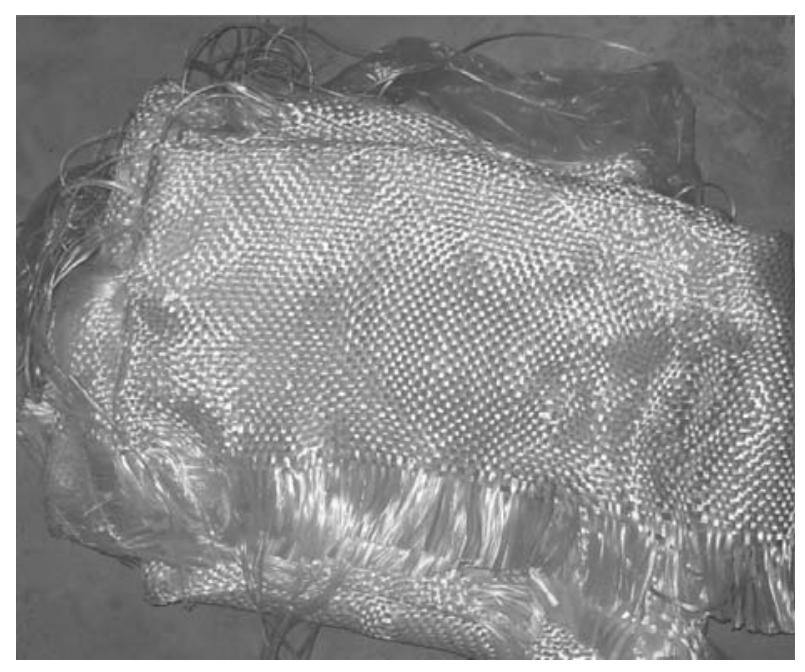

Fig. 1. Glass fibre

\section{Mix Proportions}

Indian standard method of mix design method was followed to arrive at the trial mix proportion for $M_{30}$ grade of concrete. The final mix proportion mix adopted was 1: 1.12: 2.73 , Water-Cement ratio $=0.42$

Table 1. Mix Proportion

\begin{tabular}{|c|l|l|}
\hline SI No & \multicolumn{1}{|c|}{ Description } & \multicolumn{1}{|c|}{ Parameters } \\
\hline 1. & Grade of concrete & $M_{30}$ \\
\hline 2. & Max size of aggregate & $20 \mathrm{~mm}$ \\
\hline 3. & Cement & $449.5 \mathrm{Kg} / \mathrm{m}^{3}$ \\
\hline 4. & Fine aggregate & $504 \mathrm{Kg} / \mathrm{m}^{3}$ \\
\hline 5. & Coarse aggregate & $1227 \mathrm{Kg} / \mathrm{m}^{3}$ \\
\hline 6. & Water Cement Ratio & 0.42 \\
\hline 7. & Water & $188.8 \mathrm{litres} / \mathrm{m}^{3}$ \\
\hline 8. & $\begin{array}{l}\text { Target mean strength } @ 28 \\
\text { days Comp. strength }\end{array}$ & $38.25 \mathrm{~N} / \mathrm{mm}^{2}$ \\
\hline
\end{tabular}




\section{EXPERIMENTAL WORK}

A total of 150 numbers of concrete specimens were cast with and without fibres in this experimental work. The specimens cast in this study consist of 50 numbers of cubes, 50 numbers of cylinders and 50 numbers of beams. The mix proportion used for casting the specimens was 1: 1.12: 2.73: 0.42 (Cement: Sand: Coarse aggregate: water-cement ratio) Glass fibre is varied from $0 \%$ to $6 \%$ percentage by weight of concrete. Cement, sand and coarse aggregate were mixed in dry state using a laboratory mixer and then fibres were added in stages of small quantities and mixed further. Then required quantity water was added and mixed thoroughly. Specimens were cast in $\mathrm{Cl}$ moulds using table vibrators. The specimen were removed from the mould after 24 hours and then cured under water for a period of $7,14,28$ days. The specimens were taken out from the curing tank just prior to the test. The tests for compressive, tensile, and flexural were conducted using compression testing machine and Universal Testing Machine. These tests were conducted as per relevant IS code specifications. The details of the various tests and dimensions of the specimens are tabulated in table 2 . These specimens were tested for the required age and mean value is reported and the details are given below.

Table 2. Type of test and Size of Specimens

\begin{tabular}{|c|l|l|l|}
\hline $\begin{array}{c}\text { Sl. } \\
\text { No. }\end{array}$ & \multicolumn{1}{|c|}{ Type of Test } & $\begin{array}{c}\text { Type of } \\
\text { Specimen }\end{array}$ & \multicolumn{1}{|c|}{$\begin{array}{c}\text { Dimensions } \\
\text { Are In Mm }\end{array}$} \\
\hline 1. & Compression test & Cubes & $150 \times 150 \times 150$ \\
\hline 2. & Split tension test & Cylinders & $\begin{array}{l}150 \text { diameter, } \\
300 \text { height }\end{array}$ \\
\hline 3. & Flexural test & Beams & $500 \times 100 \times 100$ \\
\hline
\end{tabular}

A. Testing

\section{A.1. Compression Test}

Compression test is the most common test conducted on hardened concrete, partly because it is an easy test to perform, and partly because most of the desirable characteristics properties of concrete are qualitatively related to its compressive strength. The compression strength test is carried out on cube specimen of size $150 \times 150 \times 150 \mathrm{~mm}$. The smooth surfaces of the specimen were placed between the platens of compression testing machine, subjected to
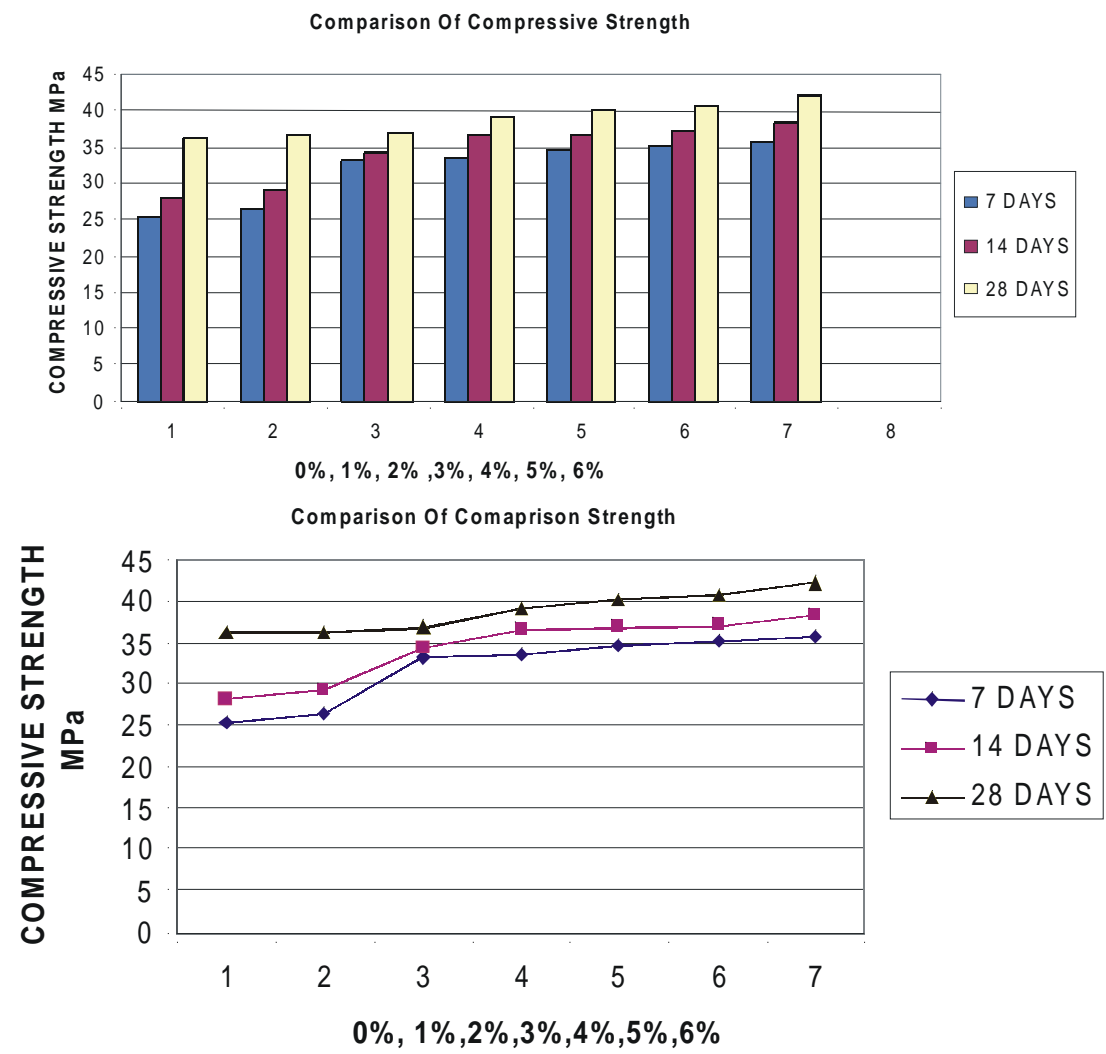

Fig. 2. Increase in Compressive Strength Vs \% Glass Fibre Content 
gradual loading and the ultimate load at failure was noted and the results of test specimens were tabulated in the Table 3.

Table 3. Comparison of Average Compressive Strength

\begin{tabular}{|l|c|c|c|}
\hline \multirow{2}{*}{$\begin{array}{c}\text { Concrete Cubes } \\
\text { With Glass Fibres }\end{array}$} & \multicolumn{3}{|c|}{ Mean Compressive Strength } \\
\cline { 2 - 4 } & 7 Days & 14 Days & 28 Days \\
\hline Glass Fibre 0\% & 25.42 & 28 & 36.22 \\
\hline Glass Fibre 1\% & 26.52 & 29.12 & 36.35 \\
\hline Glass Fibre 2\% & 33.12 & 34.25 & 36.88 \\
\hline Glass Fibre 3\% & 33.58 & 36.54 & 39.12 \\
\hline Glass Fibre 4\% & 34.52 & 36.86 & 40.16 \\
\hline Glass Fibre 5\% & 35.26 & 37.24 & 40.85 \\
\hline Glass Fibre 6\% & 35.80 & 38.22 & 42.12 \\
\hline
\end{tabular}

Table 4. Strength to Weight Ratio

\begin{tabular}{|c|c|c|c|}
\hline $\begin{array}{c}\text { Type Of } \\
\text { Concrete }\end{array}$ & $\begin{array}{c}\text { Compressive } \\
\text { Strength In } \\
\mathrm{N} / \mathrm{Mm}^{2}\end{array}$ & $\begin{array}{c}\text { Unit } \\
\text { Weight } \\
\mathrm{Kn} / \mathrm{M}^{3}\end{array}$ & $\begin{array}{c}\text { Strength } \\
\text { To Weight } \\
\text { Ratio }\end{array}$ \\
\hline Glass Fibre 0\% & 36.22 & 24.00 & 1.50 \\
\hline Glass Fibre 1\% & 36.35 & 24.24 & 1.49 \\
\hline Glass Fibre 2\% & 36.88 & 24.48 & 1.50 \\
\hline Glass Fibre 3\% & 39.12 & 24.72 & 1.58 \\
\hline Glass Fibre 4\% & 40.16 & 24.96 & 1.60 \\
\hline Glass Fibre 5\% & 40.85 & 25.20 & 1.62 \\
\hline Glass Fibre 6\% & 42.12 & 25.44 & 1.65 \\
\hline
\end{tabular}

It is seen that the strength to weight ratio achieved for glass is 3.62 . This value is higher than that obtained for plain concrete. This higher strength to weight ratio will be of great use for the design of cost effective structures using glass. Bar chart of strength to weight ratio is also shown in fig 3 .

\section{A.2. Split Tensile Strength Test}

The split tensile test is simple to perform and gives more uniform results than other tension tests. The Strength determined in the splitting test is believed to be closer to the true tensile strength of concrete, than the modulus rupture. The test was

carried out by placing a cylindrical specimen horizontally between the loading surfaces of a

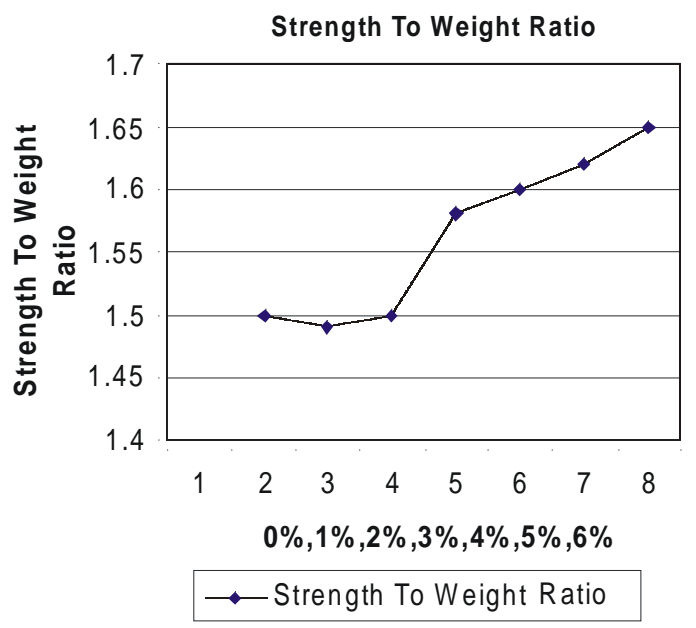

Fig. 3. Strength to Weight Ratio

compression-testing machine and load is applied until failure of the cylinder, along the diameter. The results of test split tensile test specimens were tabulated in the table 5 .

\section{A.3. Flexural Test by Third-Point Loading}

The specimens are loaded and tested in accordance with the ASTM Test Method C 78. The third- point loading method with the forces applied perpendicular to the beam without eccentricity.

Loading is done continuously without any shock. Reaction shall be parallel to the direction of the applied force at all times during the test and the ratio of distance between the point of load application and nearest reaction to the depth of the beam shall not be less than one.

\section{Table 5. Average Split Tensile Strength Results}

\begin{tabular}{|l|c|c|c|}
\hline \multirow{2}{*}{$\begin{array}{l}\text { Concrete Cylinders } \\
\text { With Glass Fibres }\end{array}$} & \multicolumn{3}{|c|}{ Mean Split Tensile Strength } \\
\cline { 2 - 4 } & 7 Days & 14 Days & 28 Days \\
\hline Glass Fibre 0\% & 2.35 & 2.51 & 2. \\
\hline Glass Fibre 1\% & 2.83 & 2.87 & 2.95 \\
\hline Glass Fibre 2\% & 2.97 & 3.06 & 3.13 \\
\hline Glass Fibre 3\% & 2.99 & $3 . .10$ & 3.15 \\
\hline Glass Fibre 4\% & 3.01 & 3.17 & 3.22 \\
\hline Glass Fibre 5\% & 3.25 & 3.34 & 3.39 \\
\hline Glass Fibre 6\% & 3.43 & 3.49 & 3.52 \\
\hline
\end{tabular}




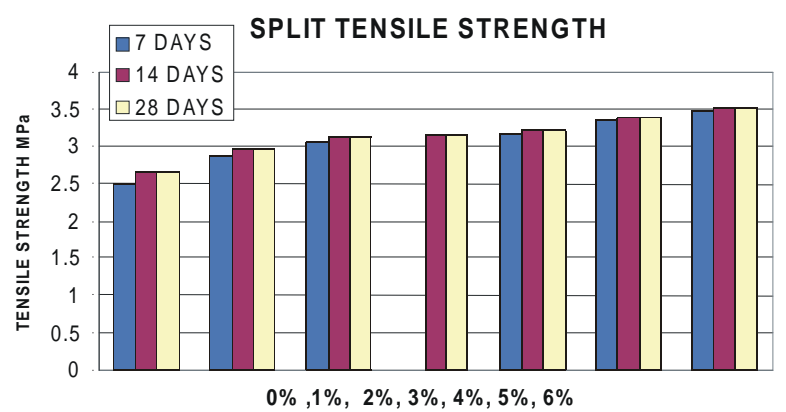

Fig. 4. Split Tensile Strength

Table 6. Average Flexural Strength Results

\begin{tabular}{|l|c|c|c|}
\hline $\begin{array}{c}\text { Concrete } \\
\text { Prisms With } \\
\text { Glass Fibres }\end{array}$ & \multicolumn{3}{|c|}{ Mean Flexural Strength $\mathrm{N} / \mathrm{mm}^{2}$} \\
\cline { 2 - 4 } & 7 Days & 14 Days & 28 Days \\
\hline Glass Fibre 0\% & 4.26 & 4.33 & 4.78 \\
\hline Glass Fibre 1\% & 4.29 & 4.70 & 4.82 \\
\hline Glass Fibre 2\% & 4.71 & 4.98 & 5.27 \\
\hline Glass Fibre 3\% & 4.90 & 5.12 & 5.43 \\
\hline Glass Fibre 4\% & 5.06 & 5.10 & 5.26 \\
\hline Glass Fibre 5\% & 5.34 & 5.53 & 5.79 \\
\hline Glass Fibre 6\% & 5.70 & 5.78 & 5.82 \\
\hline
\end{tabular}
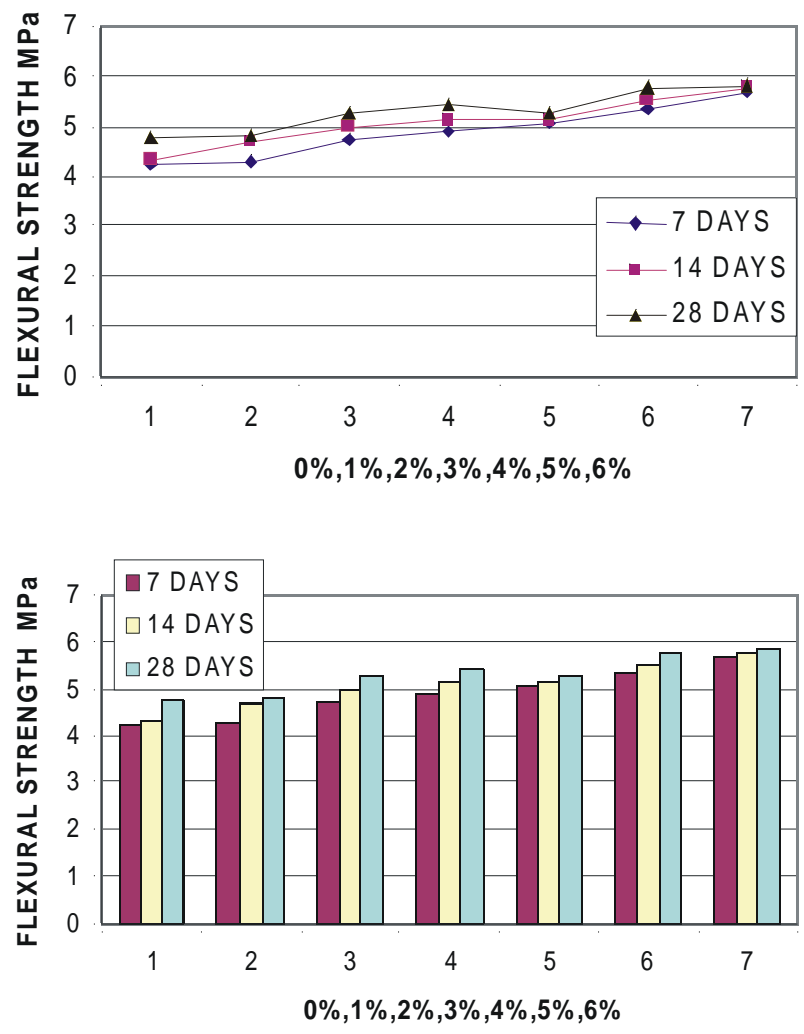

Fig. 5. Average Flexural Strength

\section{RESULTS AND DISCUSSION}

The test results of compression, tension and flexure at the end of 7 days, 14 days and 28 days are presented in table 3, 4, 5 and 6 respectively. The results reported are average of three specimen. The individual variation is within $\pm 15 \%$ of the average and it satisfies requirement of BIS: $456-2000$.

It is clear that the addition of glass fibres in the plain concrete enhances its strength under compression, tension and flexure. The strength to weight ratio is increased from 1.50 to 1.65 . It is observed that $6 \%$ glass increases the strength about $14.5 \%$ at 28 days. The increase in tensile strength achieved by adding glass fibre is $43.36 \%$. It was observed that the increase in strength of flexure is up to $22 \%$. The test results increases linearly when percentage weight of fibre increased linearly. Fig 2, 3, 4 , and 5 shows the linearity in strength increase.

\section{CONCLUSION}

Based on the experimental investigations the following conclusions are arrived, It is possible to make higher strength of FRC by adding glass fibre in concrete. Inclusion of $6 \%$ glass fibres in concrete enhances its compressive strength by $14.5 \%$ at 28 days. The increase in tensile strength achieved by adding glass fibre is $42.12 \%$.. The strength to weight ratio achieved for Glass Fibre Concrete is $8 \%$ higher than plain concrete. The higher strength to weight ratio will be useful for design of cost effective structures. Economy can be achieved with the use of more deformed fibres such as wavy fibres as the fibre content required would be less to achieve target strength. The metal glass did not affect workability of the concrete so there is no need for addition of any water reducers in the concrete. The glass fibre is better than that of Plain concrete and other industrial FRC in terms of strength, strength-to-weight ratio and cost, so it can be used for the construction of structures subjected to seismic, impact, dynamic, etc loadings. From this investigation it is finally concluded that it is economical for making FRC with glass fibre.

\section{REFERENCES}

[1] Amit Mittal., Kaisare,.M.B. and Shetti,.R.G. 2004, "Use of SCC in a pump house at TAPP3\&4,Tarapur", The Indian Concrete Journal, June, pp30-34.

[2] Bapat,.S.G., Kulkarni.,S.B. and Bandekar,.K.S., 2004, "Using SCC in nuclear power plants-Laboratory and 
mock-up trials at Kaiga", The Indian Concrete Journal, June, pp51-57.

[3] Basu.C.Prabir and Subrato Chowdhury., 2007, "Impact of fine aggregate particle size on mortar rheology for SCC," The Indian Concrete Journal,January,pp7-14.

[4] Reaffirmed 1999, IS 516-1959, "Indian Standard code of practice for Methods of tests for strength of concrete", Bureau of Indian Standards, New Delhi.

[5] Nataraja M.C., Dhang and N. Gupta A.P. 1998. "Steel fibre reinforced concrete under compression" The Indian Concrete Journal.

[6] Bayasi.Z and Soroushian .P 1989 "Optimum use of pozzalanic materials in steel fibre reinforced concrete" Transportation research record No.1226.

[7] Shetty M.S., Chand S., 2004 "Concrete Technology" by and Co Ltd., New Delhi.
[8] IS 10262-1982 IS Recommended guide lines for Concrete Mix Design.

[9] SP-23 Hand book of Concrete Mixes based on IS standards.

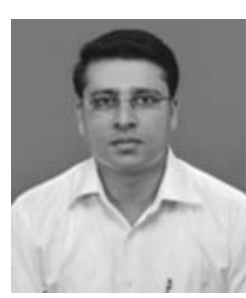

Kannan is a research scholar at the department of Civil Engineering, Sathyabama University, Chennai. He is post graduate in Construction Engineering and Management from SASTRA University and a graduate in Civil engineering from Madurai

Kamaraj University. He has over 7 years of teaching experience and his field of research is Analysis \& Design of Folded Plates. 